\title{
PENINGKATAN PENGETAHUAN KESEHATAN WUS TERKAIT HIV/AIDS MELALUI PENYULUHAN KESEHATAN
}

\author{
Sutrisni 1), Nara Lintan Mega Puspita 2), Halimatus Saidah 3) \\ ${ }_{1}$ Prodi DIV Kebidanan, Fakultas Ilmu Kesehatan, Universitas Kadiri \\ sutrisni@unik-kediri.ac.id \\ ${ }_{2}$ Prodi DIV Kebidanan, Fakultas Ilmu Kesehatan, Universitas Kadiri \\ naralintan@unik-kediri.ac.id
}

${ }_{3}$ Prodi DIV Kebidanan, Fakultas Ilmu Kesehatan, Universitas Kadiri y.midwife@yahoo.com

\begin{abstract}
ABSTRAK
HIV AIDS adalah penyakit yang menyerang sistem kekebalan tubuh. Hingga saat ini belum didapatkan obat yang dapat mengatasi penyakit ini, sehingga upaya yang dapat kita lakukan untuk mencegah adanya penyebaran penyakit tersebut menjadi lebih luas adalah dengan melakukan pencegahan, namun pengetahuan masyarakat dalam melakukan pencegahan terhadap HIV AIDS masih sangat kurang. Untuk itu kami berupaya untuk melakukan penyuluhan dan kampanye tentang HIV AIDS ini. Adapun sasaran dari kegiatan penyuluhan ini adalah kaum perempuan, terutama wanita usia subur (WUS) yang sudah aktif dalam kegiatan seksual. Perempuan berisiko dan lebih rentan terpapar HIV AIDS dibandingkan dengan laki-laki yang dimungkinkan karena beberapa faktor. Jumlah Peserta dari kegiatan ini adalah 30 orang pada hari pertama dan 28 orang pada hari kedua. Hasil evaluasi yang dilakukan menyimpulkan bahwa kegiatan penyuluhan yang dilakukan memiliki peran yang penting dalam peningkatan pengetahuan peserta yang hadir, dibuktikannya dengan adanya peningkatan pengetahuan dari peserta
\end{abstract}

Kata kunci : HIV, AIDS, Perempuan, WUS, Pencegahan

\section{PENDAHULUAN}

Acquired Immunodeficiency Syndrome (AIDS) adalah penyakit yang disebabkan oleh Human Immunodeficiency Virus (HIV), mekanisme penyebarannya dengan cara menyerang sel darah putih sehingga sistem kekebalan tubuh manusia menjadi rusak. Kasus HIV/AIDS merupakan fenomena gunung es, sebab jumlah kasus yang dilaporkan jauh lebih sedikit 
dibandingkan dengan faktanya. Hal ini terlihat dari laporan jumlah kasus AIDS yang setiap tahunnya meningkat secara signifikan (Purwaningsih, 2008).

Di seluruh dunia, pada tahun 2013 terdapat 35 juta orang yang hidup dengan HIV. Jumlah penderita HIV tersebut terdiri dari 16 juta perempuan dan 3,2 juta anak usia $<15$ tahun. Jumlah penderita infeksi baru sebesar 2,1 juta, yang terdiri dari 1,9 juta dewasa dan 240.000 anak usia $<15$ tahun. Jumlah kematian akibat AIDS sebanyak 15 juta orang dengan 1,3 juta penderitanya adalah usia dewasa dan 190.000 adalah anak <15 tahun (Kemenkes RI, 2014)

Di Indonesia, pada tahun 2016 didapatkan data jumlah penderita hiv sebanyak 17.847 orang dan AIDS 8.267 orang. Jawa Timur adalah propinsi dengan jumlah penderita infeksi HIV terbanyak, yaitu 2. 659 orang, dan 630 orang dinyatakan AIDS (Kemenkes, 2016). Di Kabupaten Kediri, kasus "Human Immuno Deficiency Virus/ Aquired Immuno Defficiency Syndrome" (HIV AIDS) pada tahun 2016 mencapai 615 kasus, dengan jumlah penderita yang meninggal sebanyak 183 orang (Dinkes Kabupaten Kediri, 2016).

Perempuan adalah kaum yang rentan terpapar HIV AIDS, meskipun belum ada bukti bahwa HIV secara klinis memiliki dampak yang lebih buruk pada perempuan. Namun beberapa penelitian memberi kesan bahwa HIV lebih berpengaruh pada perempuan dibandingkan dengan laki-laki (Anonim, 2014). Dilihat dari segi biologis, bentuk organ reproduksi perempuan memungkinkan lebih banyak menampung cairan mani dari suami yang mungkin terinfeksi virus HIV. Apalagi kondom khusus perempuan belum dijual bebas, dan harganya juga jauh lebih mahal dibandingkan kondom untuk pria, serta masih kurang diminati pemakaiannya karena alasan yang beragam. Selain sisi biologis, sisi sosial juga memungkinkan menjadi penyebab rentannya perempuan terhadap HIV, hal ini karena tak sedikit perempuan memiliki tugas rangkap, selain mengurus rumah tangga, tak sedikit perempuan yang bekerja untuk membantu perekonomian keluarga. Adanya tugas rangkap tersebut membuat perempuan sering kali baru memeriksakan diri setelah sangat terlambat, ketika sudah dalam kondisi sakit dan sudah pada fase AIDS.

Berdasarkan uraian di atas, kami merasa perlu untuk diadakan penyuluhan tentang HIV AIDS sebagai upaya peningkatan pengetahuan warga terhadap HIV AIDS, dengan meningkatnya pengetahuan tentang HIV AIDS di harapkan warga dapat lebih berhati-hati agar terhindar dari ancaman infeksi virus tersebut.

\section{METODE PELAKSANAAN}

Sasaran dalam kegiatan ini adalah remaja dengan rentan usia 15-24 tahun di wilayah Kelurahan Pesantren Kecamatan Ngasem Kabupaten Kediri. Kegiatan ini dilakukan selama tiga hari, pada 
tanggal 1 sampai 3 Desember 2017 dengan dibantu oleh 10 orang mahasiswa. Adapun rincian kegiatan yang dilakukan adalah sebagai berikut:

\begin{tabular}{|c|c|c|c|}
\hline TANGGAL & LOKASI & KEGIATAN & $\begin{array}{c}\text { ALAT DAN BAHAN } \\
\text { YANG } \\
\text { DIGUNAKAN }\end{array}$ \\
\hline 1 Desember 2017 & Rumah Warga & $\begin{array}{l}\text { Penyuluhan tentang } \\
\text { HIV AIDS }\end{array}$ & Leaflet \\
\hline 2 Desember 2017 & Rumah Warga & $\begin{array}{l}\text { - Follow up terhadap } \\
\text { penyuluhan yang } \\
\text { sudah diberikan } \\
\text { - Memberikan } \\
\text { doorprise untuk } 3 \\
\text { orang yang } \\
\text { berhasil menjawab } \\
\text { pertanyaan } \\
\text { penyuluh dengan } \\
\text { benar } \\
\text { - Memberikan } \\
\text { souvenir bagi } \\
\text { peserta yang hadir }\end{array}$ & $\begin{array}{l}\text { 1. Doorprice: } \\
\text { a. Dompet } \\
\text { b. Payung } \\
\text { c. Kaos } \\
\text { 2. Souvenir berupa } \\
\text { kalender } 2018\end{array}$ \\
\hline 3 Desember 2017 & $\begin{array}{l}\text { Car Free Day } \\
\text { Simpang Lima } \\
\text { Gumul Kabupaten } \\
\text { Kediri }\end{array}$ & $\begin{array}{l}\text { - Kampanye } \\
\text { terhadap bahaya } \\
\text { HIV AIDS } \\
\text { - Pembagian pita } \\
\text { - Pembagian leafleat } \\
\text { - Pembuatan cap } \\
\text { tangan sebagai } \\
\text { bentuk simbolis } \\
\text { partisipasi warga } \\
\text { dalam pencegahan } \\
\text { HIV AIDS }\end{array}$ & $\begin{array}{l}\text { 1. Pita merah } \\
\text { 2. Leafleat } \\
\text { 3. Kain putih ukuran } 1 \\
\text { x } 3 \text { meter } \\
\text { 4. Cat air } \\
\text { 5. Baskom } \\
\text { 6. Bak cuci tangan } \\
\text { 7. Tissue }\end{array}$ \\
\hline
\end{tabular}

\section{HASIL DAN PEMBAHASAN}

a. Sasaran dan Target

\begin{tabular}{cccc}
\hline \multirow{2}{*}{ Tanggal kegiatan } & \multicolumn{2}{c}{ Jumlah Peserta } & \multirow{2}{*}{ Persentase (\%) } \\
\cline { 2 - 3 } & Target & Hadir & 100 \\
\hline 1 Desember 2017 & 30 & 30 & 93 \\
\hline 2 Desember 2017 & 30 & 28 & $114 \%$ \\
\hline 3 Desember 2017 & 100 & 114 & \\
\hline
\end{tabular}




\section{b. Pencapaian hasil}

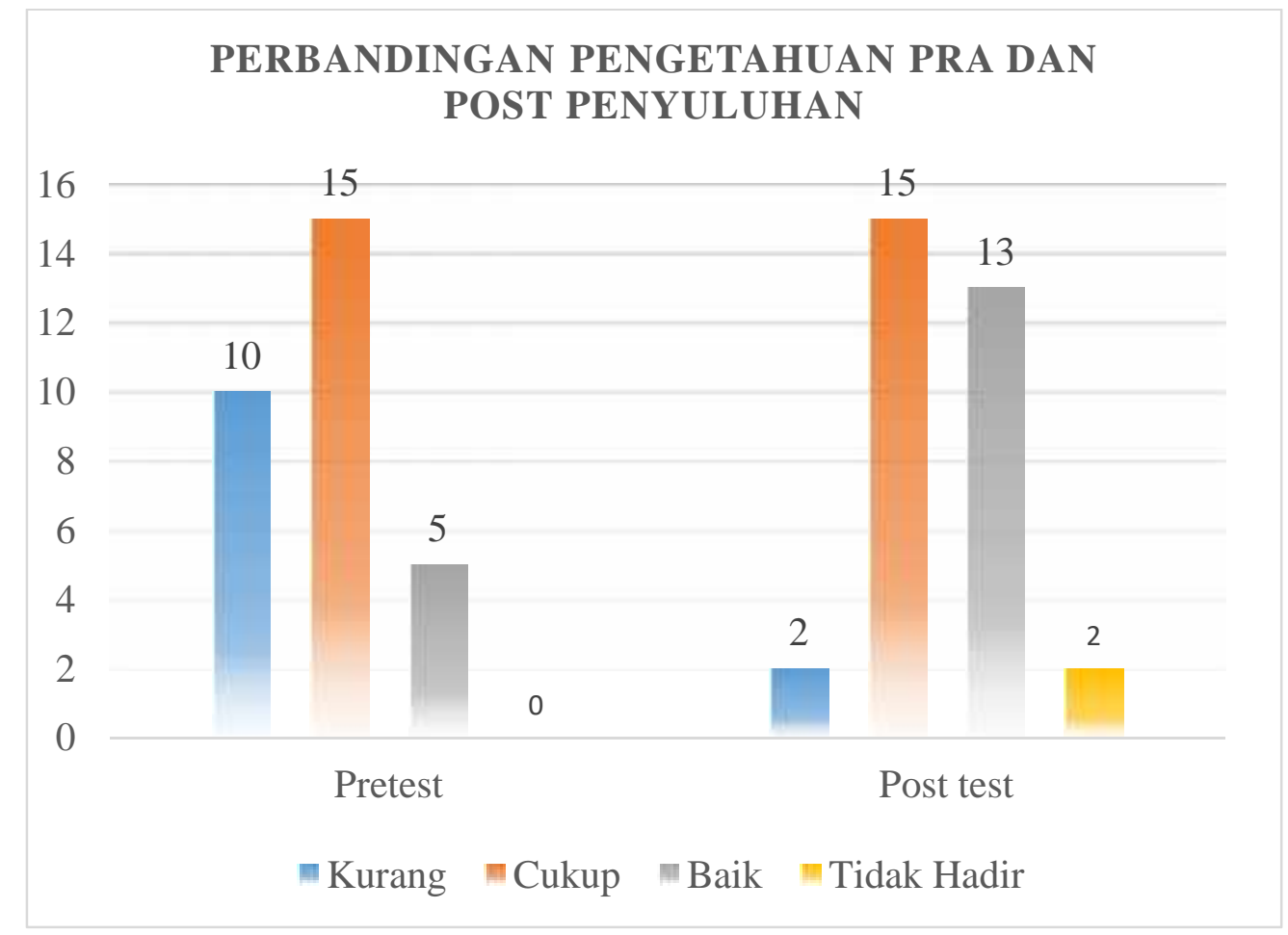

\section{c. Evaluasi hasil Kegiatan}

Peserta penyuluhan sangat antusias dengan materi yang diberikan. Adanya instrumen berupa leaflet sangat membantu peserta yang ingin membaca kembali isi materi yang telah disampaikan, sehingga peserta dapat mengingat kembali apabila ada materi yang lupa.

Pada hari kedua penyuluhan, didapatkan dua peserta yang tidak hadir, dikarenakan ada kepentingan lain, namun tidak mengurangi minat dari peserta lain. Peserta yang hadir mengaku senang dengan adanya penyuluhan yang dilakukan, terutama dengan adanya doorprice dan souvenirnya diberikan, hal tersebut menambah antusias peserta penyuluhan

Bersamaan dengan hari HIV AIDS sedunia, pada hari ketiga kami melakukan kampanye dan beberapa kegiatan lain, seperti pembagian leaflet, penyematan pita dan cap tangan sebagai bentuk secara simbolik terhadap dukungan dan partisipasi warga dalam mencegah HIV AIDS yang berlokasi di car free day Simpang Lima Gumul Kabupaten Kediri. Masyarakat sangat antusias dalam kegiatan ketiga ini, terlihat dari banyaknya peserta yang datang ke stand yang kami sediakan melebihi dari peserta yang kami targetkan. Peserta yang kami targetkan adalah 100 orang, namun yang hadir sebanyak 114 orang. 
Untuk lebih jelasnya bisa dilihat dari dokumentasi-dokumentasi berikut:

1) Hari Pertama, tanggal 01 Desember 2017

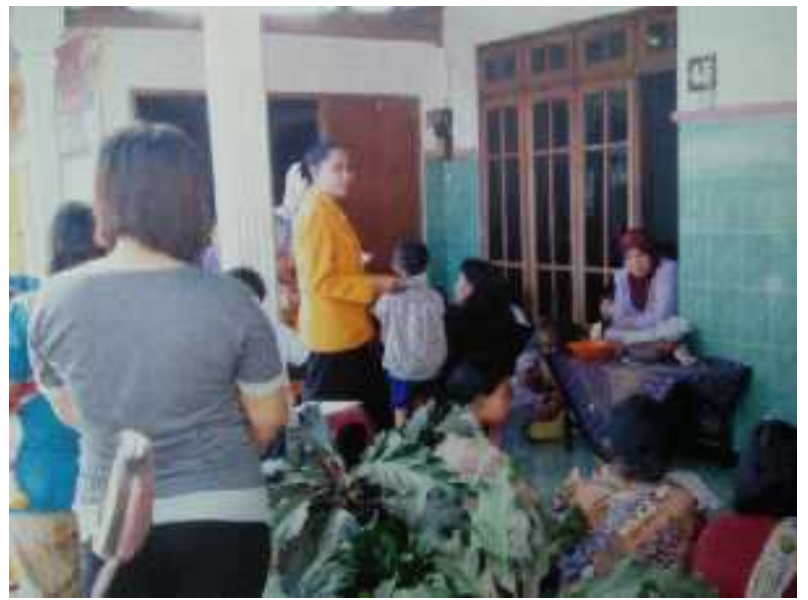

Mahasiswa Sedang Memberikan Pengarahan Terhadap Peserta Penyuluhan

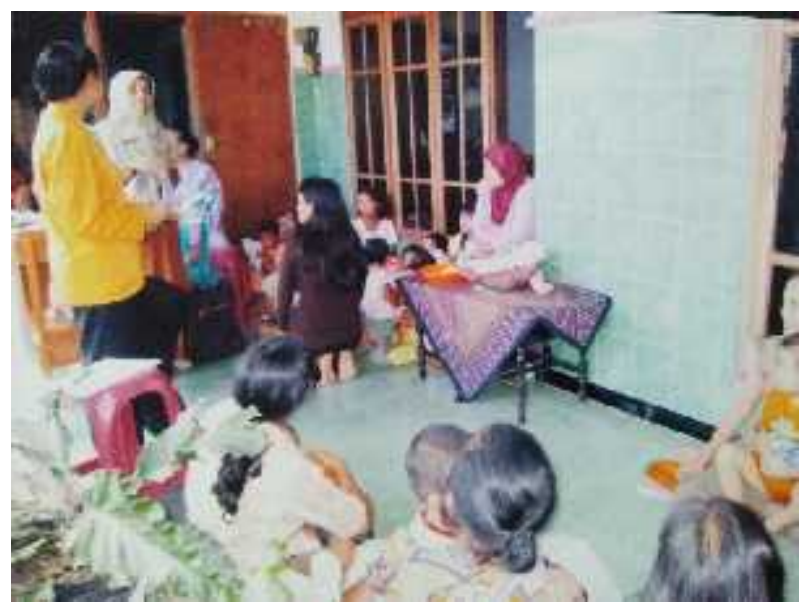

Peserta Mendengarkan Penyuluhan Yang Diberikan

2) Hari Kedua, tanggal 02 Desember 2017

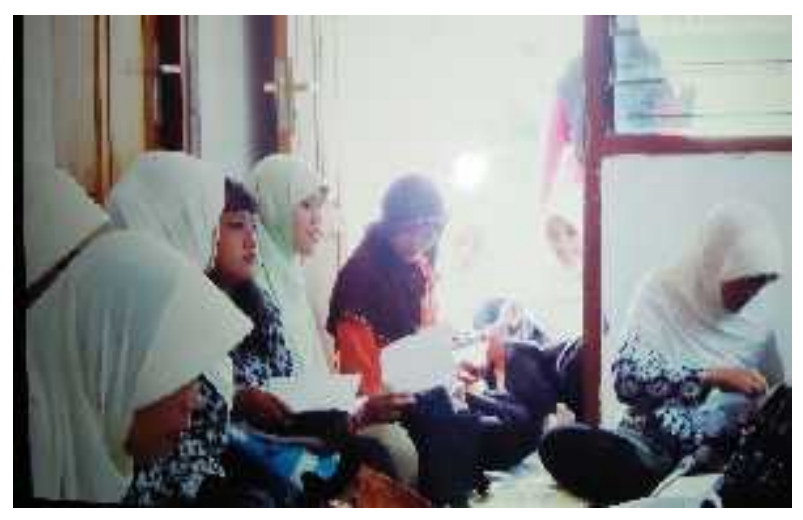

Peserta Penyuluhan Hari Kedua 


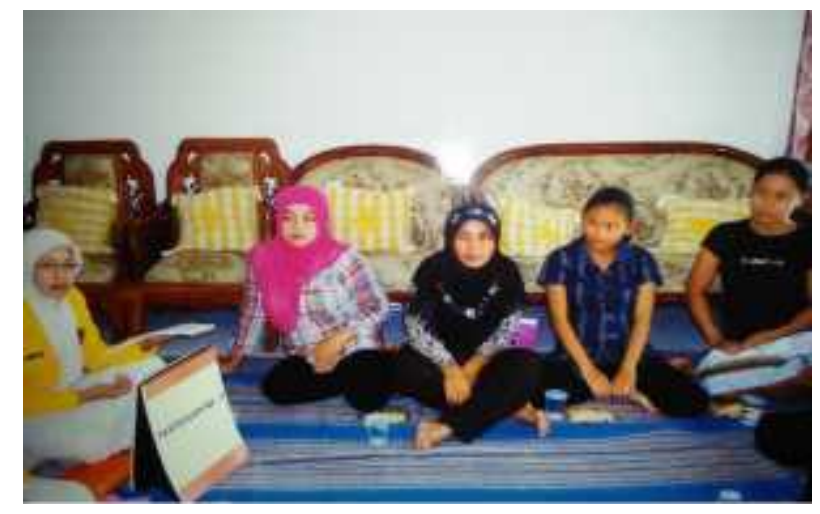

Penyuluhan Hari Kedua Dibantu Mahasiswa

3) Hari Ketiga, tanggal 03 Desember 2017

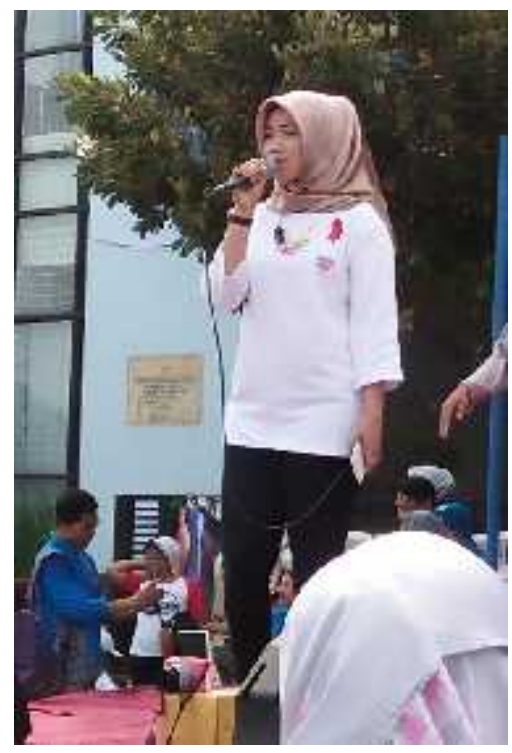

Kampanye hari HIV AIDS Oleh Ibu Sutrisni

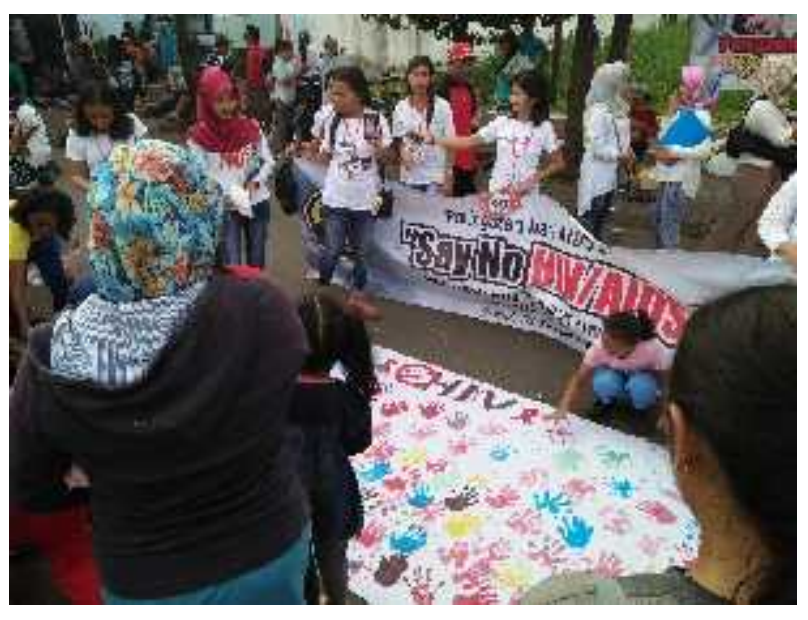

Pembuatan Cap Tangan Sebagai Bentuk Partisipasi Warga Dalam Pencegahan HIV AIDS 


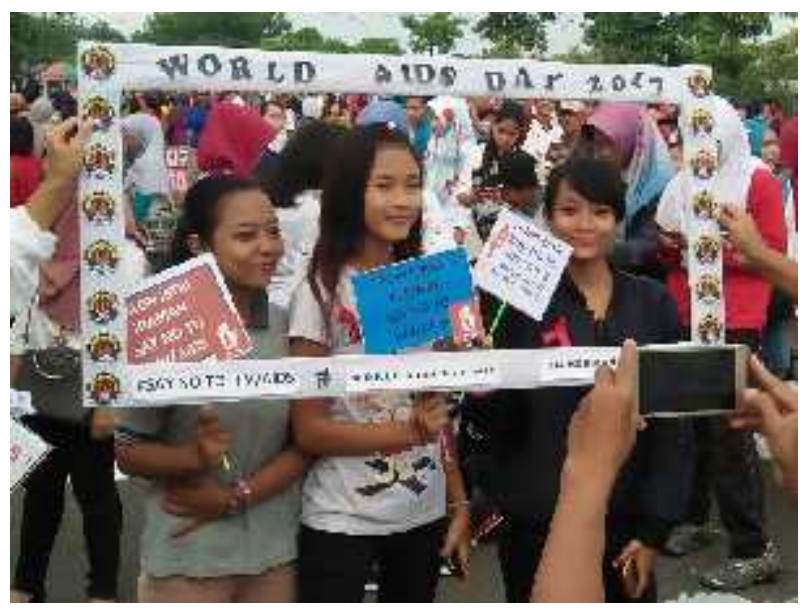

Tidak Hanya Ibu-Ibu, Tetapi Juga Banyak Remaja Yang Turut Antusias Dengan Kegiatan Ini

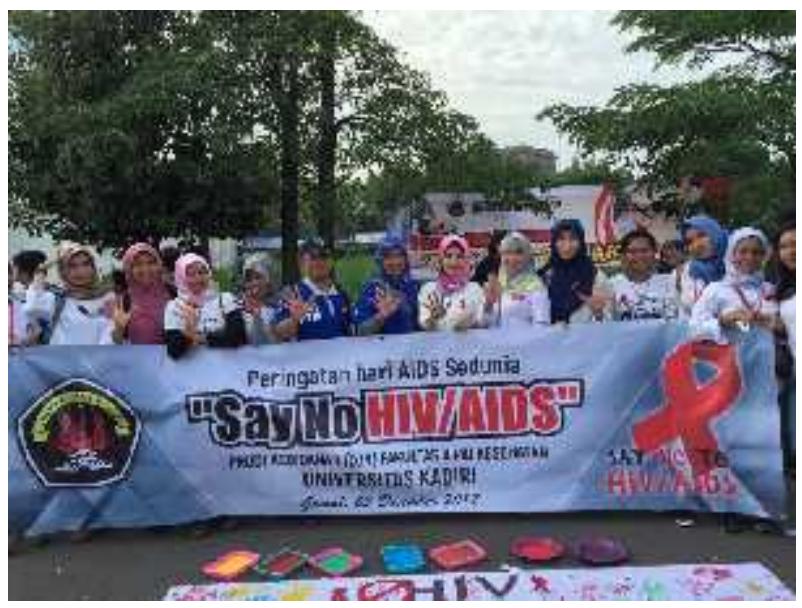

Foto Bersama Dosen, Mahasiswa Dan Pengawas Dari Dinas Kesehatan Kabupaten Kediri 


\section{DAFTAR PUSTAKA}

Purwaningsih, S. S. 2008. Perkembangan HIV dan AIDS di Indonesia. Jurnal Kependudukan Indonesia; 3 (2): 11 - 16

Ramadhan, Hasan. 2013. Perempuan Lebih Rentan Tertular HIV/AIDS. https://www.jurnal perempuan.org/perempuan-lebih-rentan-tertular-hivaids.html. Diakses 25 November 2017

2014. Apakah HIV Berpengaruh pada Perempuan secara Berbeda?. http//spiritia.or .id/li/bacali.php?lino=610. Diakses 25 November 2017

2014. Situasi dan Analisis HIV AIDS. Jakarta : Infodatin Pusat Data dan Informasi Kementrian Kesehatan RI

. 2016. Laporan Situasi perkembangan HIV AIDS dan PIMS di Indonesia April-Juni 2016. Jakarta : Ditjen P2P Kementrian Kesehatan RI.

2016. Situasi Kasus HIV/ AIDS Pemerintah Kabupaten Kediri. http://dinkes.kedirikab.go .id/?hal=dbet\&id=89. Diakses tanggal 25 November 2017 


\section{LAMPIRAN}




\title{
SATUAN ACARA PENYULUHAN PENULARAN DAN PENCEGAHAN HIV AIDS
}

\author{
Hari, tanggal : Jumat, 01 Desember 2017 \\ Tempat $\quad$ : Rumah Warga, di Kel. Tugurejo, Kec. Ngasem, Kab. Kediri \\ Waktu pertemuan : 30 menit \\ Sasaran : Wanita Usia Subur \\ Materi : HIV AIDS
}

1. TUJUAN

\subsection{Tujuan Instruksional Umum}

Setelah dilakukan penyuluhan tentang HIV AIDS, Wanita Usia Subur yang hadir dapat mengerti tentang HIV AIDS dari segi penularan dan pencegahan

\subsection{Tujuan Instruksional Khusus}
a. Menjelaskan pengertian HIV AIDS
b. Menjelaskan tentang media penularan HIV
c. Menjelaskan tentang cara penularan HIV
d. Menjelaskan tahapan perkembangan infeksi HIV menjadi AIDS
e. Menjelaskan pencegahan HIV AIDS
f. Menjelaskan mengetahui status HIV
g. Menjelaskan fakta dari mitos HIV

\section{MATERI PEMBELAJARAN}

2.1 Pengertian HIV AIDS

2.2 Media penularan HIV AIDS

2.3 Cara penularan HIV AIDS

2.4 Tahapan HIV menjadi AIDS

2.5 Pencegahan HIV AIDS

2.6 Cara Mengetahui status HIV

2.7 Pembenaran mitos Penularan HIV AIDS

3. METODE PEMBELAJARAN

3.1 Ceramah

3.2 Diskusi

4. MEDIA

Leaflet 
5. RINCIAN KEGIATAN

\begin{tabular}{|c|c|c|c|}
\hline Tahapan & Waktu & Kegiatan Penyuluh & Kegiatan \\
\hline Pendahuluan & 5 menit & $\begin{array}{l}\text { - } \text { Mengucapkan salam } \\
\text { - Apersepsi peserta } \\
\text { tentang HIV AIDS }\end{array}$ & $\begin{array}{l}\text { - Menjawab salam } \\
\text { - Menjawab pertanyaan } \\
\text { penyuluh }\end{array}$ \\
\hline Inti & 20 menit & $\begin{array}{l}\text { - } \text { Menyampaikan materi } \\
\text { penyuluhan } \\
\text { - Diskusi dan tanya jawab }\end{array}$ & $\begin{array}{l}\text { - Menyimak materi yang } \\
\text { disampaikan } \\
\text { - Mengikuti jalannya } \\
\text { diskusi, bertanya apabila } \\
\text { ada yang belum jelas }\end{array}$ \\
\hline Penutup & 5 menit & $\begin{array}{l}\text { - Melakukan evaluasi } \\
\text { terhadap materi yang } \\
\text { telah disampaikan } \\
\text { - Mengucapkan salam }\end{array}$ & $\begin{array}{l}\text { - } \text { Menjawab pertanyaan } \\
\text { penyuluh } \\
\text { - Menjawab salam }\end{array}$ \\
\hline
\end{tabular}

\section{EVALUASI}

\subsection{Metode : tes lisan \\ 6.2 Pertanyaan evaluasi :}

a. Apa yang dimaksud dengan HIV AIDS

Jawaban : HIV adalah virus yang menyerang kekebalan tubuh dan aids adalah kumpulan gejala yang diakibatkan karena berkurangnya daya tahan tubuh akibat infeksi virus HIV

b. Melalui apa HIV dapat menular?

Jawaban : media penularan HIV antara lain : darah, air mani, cairan vagina, air susu ibu dan cairan yang terinfeksi oleh penderita HIV AIDS. Cara penularannya melalui hubungan seksual berisiko tanpa adanya pelindung, penggunaan jarum suntik yang terkontaminasi virus HIV, pada ibu dan anak bisa tertular pada proses kehamilan, persalinan atau menyusui.

c. Bagaimana cara pencegahan terhadap HIV?

Jawaban: menghindari seks bebas, setia pada pasangan, menggunakan kondom apabila melakukan hubungan seks yang berisiko dan hindari penggunaan jarum suntik bergantian (terutama pada penggunaan narkoba jenis suntik) 
d. Bagaimana kita dapat mengetahui terpapar atau tidaknya terhadap virus HIV? Jawaban : dengan datang ke klinik/ RS/ puskesmas rujukan yang menyediakan pelayanan VCT untuk melakukan konseling dan pemeriksaan laboratorium 


\section{MATERI PENYULUHAN}

HIV AIDS

\section{DEFINISI}

HIV atau Human Immunodeficiency Virus adalah virus yang menyerang sel darah putih di dalam tubuh, yang mengakibatkan kekebalan tubuh manusia menjadi menurun. Orang yang dalam darahnya terdapat virus HIV dapat tampak sehat dan belum membutuhkan pengobatan. Namun orang tersebut dapat menularkan virusnya kepada orang lain bila melakukan hubungan seks berisiko dan berbagi alat suntik dengan orang lain (Kemenkes, 2015). Sebelum HIV berubah menjadi AIDS membutuhkan waktu kira-kira 5 sampai 10 tahun (Kemenkes, 2011)

AIDS atau Acquired Immune Deficiency Syndrome merupakan sekumpulan gejala penyakit yang timbul akibat turunnya kekebalan tubuh. AIDS disebabkan oleh infeksi HIV. Akibat menurunnya kekebalan tubuh pada seseorang maka orang tersebut sangat mudah terkena penyakit (Kemenkes, 2015)

\section{MEDIA PENULARAN}
a. Darah
b. Cairan vagina
c. Cairan mani dan cairan pre-cum/getah penis
d. Air susu ibu yang tertular hiv
e. Cairan infeksi penderitanya (Kemenkes, 2011)

\section{CARA PENULARAN}

a. Melalui hubungan seks tanpa menggunakan kondom sehingga memungkinkan cairan mani atau cairan vagina yang mengandung virus HIV masuk ke dalam tubuh pasangannya

b. Dari seorang ibu hamil yang HIV positif kepada bayinya selama masa kehamilan, waktu persalinan dan/atau waktu menyusui.

c. Melalui transfusi darah/produk darah yang sudah tercemar HIV. Lewat pemakaian alat suntik yang sudah tercemar HIV, yang dipakai bergantian tanpa disterilkan, terutama terjadi pada pemakaian bersama alat suntik di kalangan pengguna narkoba suntik (penasun) (Kemenkes, 2015). 


\section{TAHAPAN HIV MENJADI AIDS}

a. Pada tahap awal, ketika HIV memasuki tubuh, tidak terdapat tanda-tanda khusus sehingga belum dapat diketahui dari tes HIV. Tahap ini disebut dengan periode jendela, berkisar antara 1 hingga 3 bulan bahkan ada yang hingga 6 bulan (HIV masih 'bersembunyi', belum bisa dideteksi).

b. Pada tahap kedua, HIV telah berkembang biak dalam tubuh sehingga dapat diketahui dari tes HIV. Orang yang tertular HIV tetap tampak sehat selama 5 sampai 10 tahun, dikenal dengan masa laten HIV/AIDS.

c. Pada tahap ketiga, sistem kekebalan tubuh semakin menurun, orang yang HIV+ akan mulai menampakkan gejala-gejala AIDS. Misalnya ditandai dengan adanya pembengkakan kelenjar limfa pada seluruh tubuh.

a. Tahap ini kira-kira berlangsung selama lebih dari 1 bulan. Pada tahap akhir, ketika sudah menjadi AIDS, penderita akan semakin lemah kondisinya akibat berbagai penyakit yang tidak dapat dilawan oleh sistem kekebalan tubuhnya. Penderita ini, pada akhirnya cepat atau lambat akan meninggal, tergantung dari kondisi penyakit yang dideritanya (Kemenkes, 2011).

\section{PENCEGAHAN HIV AIDS}

b. Abstinence - Tidak berhubungan seks bebas

c. Be Faithful-Selalu setia pada pasangan

d. Condom - Gunakan kondom di setiap hubungan seks berisiko

e. Drugs - Jauhi narkoba (narkoba jenis suntik dengan pengunaan jarum suntik bergantian) (Kemenkes, 2015)

\section{CARA MENGETAHUI STATUS HIV}

Orang yang sedang dalam tahap HIV tidak kita simpulkan secara kasat mata, karena Mereka tampak sehat dan tidak menunjukkan gejala penyakit apapun. Status terinfeksi HIV hanya dapat diketahui setelah mengikuti test HIV yang disertai konseling. Segera kunjungi fasilitas kesehatan terdekat (Klinik VCT) untuk tes HIV. Layanan test HIV biasanya berupa tes darah untuk memastikan adanya antibodi HIV di dalam sampel darah. Tes HIV bersifat sukarela dan rahasia. Sebelum melakukan tes HIV, akan dilakukan konseling untuk mengetahui tingkat risiko infeksi dari perilaku selama ini dan bagaimana nantinya harus bersikap setelah mengetahui hasil tes HIV. Untuk tes cepat dapat juga digunakan tes usapan selaput lendir mulut.

\section{MENDOBRAK MITOS HIV:}

a. HIV tidak menular melalui gigitan nyamuk atau serangga lainnya 
b. HIV tidak menular di kolam renang umum

c. HIV tidak menular melalui batuk atau bersin

d. HIV tidak menular dengan berbagi alat makan bersama

e. HIV tidak menular karena berjabat tangan

f. HIV tidak menular karena berciuman (Kemenkes, 2015) 


\section{DAFTAR PUSTAKA}

. 2015. Info HIV AIDS. http://www.aidsindonesia.or.id/contents/37/78/Info-HIVdan AIDS\#sthash.PBW53IK2.dpbs. Diakses 25 November 2015 . 2011. HIV/ AIDS dan IMS Penularan dan Pencegahan. http://perpustakaan.depkes. go.id:8180/handle/123456789/1546. Diakses 25 November 2017 


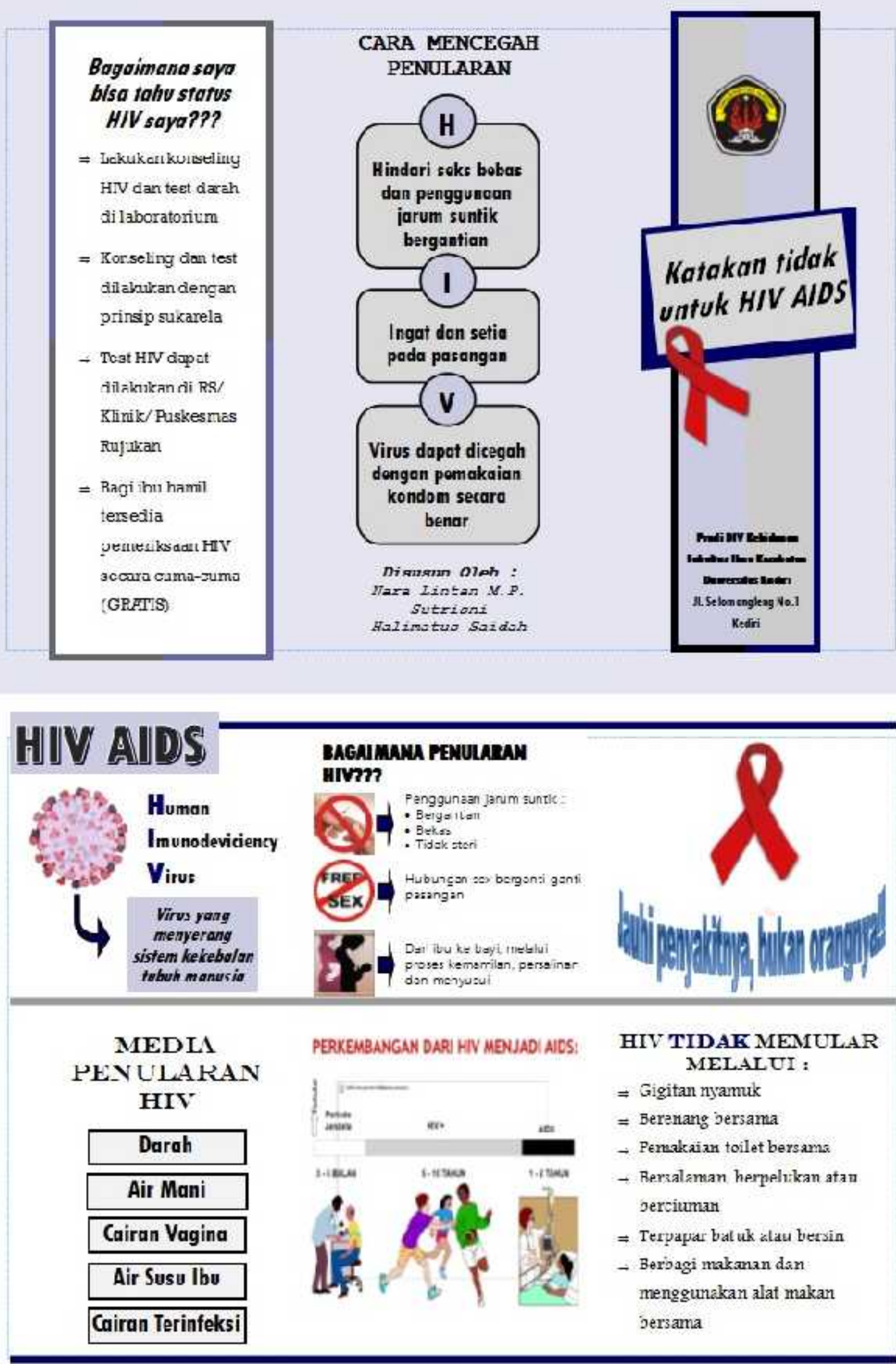

